\title{
In reply: Comment on "Anesthetic technique and cancer outcomes: a meta-analysis of total intravenous versus volatile anesthesia"
}

\author{
Andrea Yap, FANZCA (1) - Maria A. Lopez-Olivo, PhD · Julia Dubowitz, MBBS • \\ Jonathan Hiller, FANZCA $\cdot$ Bernhard Riedel, PhD $\cdot$ and \\ the Global Onco-Anesthesia Research Collaboration Group
}

Received: 3 April 2019/Revised: 16 April 2019/Accepted: 16 April 2019/Published online: 19 June 2019

(c) Canadian Anesthesiologists' Society 2019

\section{To the Editor,}

We would like to thank Chang et al. ${ }^{1}$ for identifying an error in our manuscript entitled "Anesthetic technique and cancer outcomes: a meta-analysis of total intravenous versus volatile anesthesia". ${ }^{2}$ We have re-checked all analyses in the manuscript and can confirm that this was an isolated error due to a data transcription error relating to the Oh et al. study ${ }^{3}$ within our recurrence-free survival analysis. As stated by Chang et al., when the reported

\footnotetext{
A. Yap, FANZCA $(\bowtie)$.

Department of Anaesthesia, National University Hospital, Singapore, Singapore

e-mail: andrea_yap@nuhs.edu.sg
}

Department of Anesthesia, Perioperative and Pain Medicine, Peter MacCallum Cancer Centre, Melbourne, Australia

M. A. Lopez-Olivo, $\mathrm{PhD}$

Department of General Internal Medicine, The University of Texas M.D. Anderson Cancer Center, Houston, Texas, USA

\section{J. Dubowitz, MBBS}

Department of Anesthesia, Perioperative and Pain Medicine, Peter MacCallum Cancer Centre, Melbourne, Australia

Drug Discovery Biology, Monash Institute of Pharmaceutical Sciences, Monash University, Melbourne, Australia

J. Hiller, FANZCAB. Riedel, PhD

Department of Anesthesia, Perioperative and Pain Medicine, Peter MacCallum Cancer Centre, Melbourne, Australia

Drug Discovery Biology, Monash Institute of Pharmaceutical Sciences, Monash University, Melbourne, Australia

Department of Anaesthesia and Perioperative Medicine Unit and The Sir Peter MacCallum Department of Oncology, University of Melbourne, Melbourne, Australia estimates in Oh et al. are corrected, the pooled hazard ratio (HR) is now $0.87 ; 95 \%$ confidence interval (CI), 0.66 to $1.15 ; P=0.32$ (compared with the erroneously reported HR of $0.78 ; 95 \% \mathrm{CI}, 0.65$ to $0.94 ; P<0.01$ ). Nonetheless, although now not statistically significant, the effect estimate still suggests that total intravenous anesthesia (TIVA) may be protective, albeit with a wider confidence interval that now includes 1 .

It is important to note that the Oh et al. study incorporates substantial heterogeneity $\left(\mathrm{I}^{2}>60 \%\right.$; $P=$ 0.02 ), so we performed a sensitivity analysis as we did for the other outcomes reported in the manuscript. When removing the $\mathrm{Oh}$ et al. study (as an outlier), as described in our methods, the effect estimate is 0.79 (95\% CI, 0.62 to $1.0 ; P=0.05$ ) indicating a borderline protective effect with an acceptable inconsistency score $\left(\mathrm{I}^{2}=40 \% ; P=0.16\right.$; see attached revised forest plot).

A recent editorial ${ }^{4}$ related to the important question of whether anesthetic technique impacts cancer outcomes suggested that heterogeneity in magnitude of surgical procedure within study cohorts provided "context for divergent study outcomes"; with a protective effect by propofol-TIVA on cancer recurrence and survival more likely to be seen in patients having major cancer surgery. As discussed, the study by Yoo et al. ${ }^{5}$ has substantial heterogeneity in surgical magnitude. This study also contributes to the statistical heterogeneity in our metaanalysis. When this study is also removed from analysis, the pooled estimate is statistically significant (HR, 0.71; 95\% CI, 0.59 to $0.86 ; P<0.01)$ with no heterogeneity $\left(\mathrm{I}^{2}=\right.$ $0 \% ; P=0.41$ ), further supporting our conclusions.

A major limitation of our manuscript is that our findings are based on mostly observational studies. As stated in our conclusion, there is an imperative need for robust randomized-controlled trials in this area, which will help 


\begin{tabular}{|c|c|c|c|c|c|c|}
\hline Study or Subgroup & log[Hazard Ratio] & SE & Weight & $\begin{array}{l}\text { Hazard Ratio } \\
\text { IV, Random, } 95 \% \mathrm{Cl}\end{array}$ & $\begin{array}{r}\text { Hazarc } \\
\text { IV, Rando }\end{array}$ & $\begin{array}{l}\text { d Ratio } \\
\mathrm{m}, 95 \% \mathrm{Cl}\end{array}$ \\
\hline \multicolumn{7}{|l|}{ Breast } \\
\hline Kim 2017 & -0.13 & 0.42 & $7.4 \%$ & $0.88[0.38,2.02]$ & & \\
\hline Lee 2016 & -0.74 & 0.30 & $12.8 \%$ & $0.48[0.26,0.86]$ & & \\
\hline Yan 2018 & -0.12 & 0.24 & $17.8 \%$ & $0.89[0.56,1.42]$ & & \\
\hline $\begin{array}{l}\text { Yoo } 2018 \\
\text { Subtotal (95\% Cl) }\end{array}$ & 0.04 & 0.17 & $\begin{array}{l}26.5 \% \\
64.5 \%\end{array}$ & $\begin{array}{l}1.04[0.75,1.45] \\
0.83[0.59,1.15]\end{array}$ & & \\
\hline \multicolumn{7}{|c|}{$\begin{array}{l}\text { Heterogeneity: } \text { Tau }^{2}=0.05 ; \mathrm{Chi}^{2}=5.08, \mathrm{df}=3(\mathrm{P}=0.17) ; \mathrm{I}^{2}=41 \% \\
\text { Test for overall effect: } Z=1.11(P=0.27)\end{array}$} \\
\hline \multicolumn{7}{|l|}{ Esophageal } \\
\hline $\begin{array}{l}\text { Jun } 2017 \\
\text { Subtotal }(95 \% \mathrm{Cl})\end{array}$ & -0.3507 & 0.1193 & $\begin{array}{l}35.5 \% \\
35.5 \%\end{array}$ & $\begin{array}{l}0.70[0.56,0.89] \\
0.70[0.56,0.89]\end{array}$ & & \\
\hline \multicolumn{7}{|c|}{$\begin{array}{l}\text { Heterogeneity: Not applicable } \\
\text { Test for overall effect: } Z=2.94(P<0.01)\end{array}$} \\
\hline Total $(95 \% \mathrm{Cl})$ & & & $100.0 \%$ & $0.79[0.62,1.00]$ & & \\
\hline \multicolumn{5}{|c|}{$\begin{array}{l}\text { Heterogeneity: } \mathrm{Tau}^{2}=0.03 ; \mathrm{Chi}^{2}=6.64, \mathrm{df}=4(\mathrm{P}=0.16) ; \mathrm{I}^{2}=40 \% \\
\text { Test for overall effect: } Z=1.93(\mathrm{P}=0.05) \\
\text { Test for subgroup differences: } \mathrm{Chi}^{2}=0.61, \mathrm{df}=1(\mathrm{P}=0.44), \mathrm{I}^{2}=0 \%\end{array}$} & $\begin{array}{l}0.5 \quad 0.7 \\
\text { Favours TIVA }\end{array}$ & 1.52 \\
\hline
\end{tabular}

Figure Recurrence-free survival following sensitivity analysis

to strengthen the current evidence on impact (or lack thereof) of anesthetic technique on cancer outcomes.

Conflicts of interest None declared.

Editorial responsibility This submission was handled by Dr. Hilary P. Grocott, Editor-in-Chief, Canadian Journal of Anesthesia.

\section{References}

1. Chang CY, Chien YJ, Wu MY, Kao MC, Wang SC. Comment on "Anesthetic technique and cancer outcomes: a meta-analysis of total intravenous versus volatile anesthesia. Can J Anesth 2020; https://doi.org/10.1007/s12630-019-01422-8.
2. Yap A, Lopez-Olivo MA, Dubowitz J, Hiller J, Riedel B, Global Onco-Anesthesia Research Collaboration Group. Anesthetic technique and cancer outcomes: a meta-analysis of total intravenous versus volatile anesthesia. Can J Anesth 2019; 66: 546-61.

3. Oh TK, Kim K, Jheon S, et al. Long-term oncologic outcomes for patients undergoing volatile versus intravenous anesthesia for nonsmall cell lung cancer surgery: a retrospective propensity matching analysis. Cancer Control 2018; https://doi.org/10.1177/1073274 818775360.

4. Sessler DI, Riedel B. Anesthesia and cancer recurrence: context for divergent study outcomes. Anesthesiology 2019; 130: 3-5.

5. Yoo $S$, Lee HB, Han $W$, et al. Total intravenous anesthesia versus inhalation anesthesia for breast cancer surgery: a retrospective cohort study. Anesthesiology 2019; 130: 31-40.

Publisher's Note Springer Nature remains neutral with regard to jurisdictional claims in published maps and institutional affiliations. 